in obliterating dark lines than bright ones. Prof. Wood's suggestion as to reducing the effective intensity of the truly continuous spectrum by passing the light through a suitably placed Nicol's prism, would accordingly be specially applicable to the inner corona.

Prof. Wood has obtained experimental evidence on a point to which attention was drawn many years ago by Ranyard (Mem. R.A.S., vol. xli. p. 353), namely, that if the solar light be reflected by small particles in the corona, the reflected rays will be deficient in the rays of greater wave-length. In this way the bolometric observations indicating that the corona was cooler than the bolometer are partly explained. Is it possible that the observations are to be completely explained by further supposing that the bolometer strip was outside the image of the shallow inner corona, which is probably the chief part of the corona directly emitting light and heat? The image thrown on the strip appears to have been little more than one-third of an inch in diameter, and in the account of the observations Mr. Abbot simply states that the image was brought almost tangent to the strip, so that the strip may very well have been 4 or 5 minutes from the sun's limb.

At all events, there seems to be no sufficient ground, as yet, for rejecting the view that the luminosity of the outer corona is largely due to reflected solar light, while that of the inner corona is partly due to the incandescence of solid or liquid particles and partly to gaseous radiations. A. FowLER.

Royal College of Science, South Kensington, February 9.

\section{Malaria and Mosquitoes.}

I THINK most of those who have had much experience of the Indian jungles would be prepared to corroborate the remarks made by Mr. D. E. Hutchins in last week's NATURE (p. 371), and would perhaps be inclined to think there may be something in the opinion alluded to by him, that "Dr. Ross's splendid discovery does not quite cover the whole ground." In I 873-4 I spent some months in the notoriously malarious region at the foot of the Darjiling Himalayas, which contained some tea gardens here and there at that period, while many new ones were being opened out. The planters suffered greatly from malarial fever, and I was told by several that it was far more prevalent, and of a worse type, on gardens in process of formation, by clearing the jungle and breaking up the ground, than on either the undisturbed jungle itself or on gardens that had existed for some time. In other parts of India my camp has suffered badly from malarial fever when mosquitoes were certainly not prevalent, and when, to the best of my belief, there were none, or perhaps I should rather say, none made themselves noticeable by stinging.

On the other hand, when in Upper Assam in 1874-5, I was informed by some of the planters there, and it seemed to be a commonly received opinion, that mosquito curtains were a valuable protection from malaria. Of course at that period no explanation could be given for the supposed fact, which seemed a very mysterious one, as for the invisible 'germs,' which were thought by some to float in the air, to be excluded by curtains of ordinary mesh would be something like a man being prevented from crossing a road'through inability to squeeze himself between the milestones.

I8 The Common, Ealing, February I2. F. R. MALLET.

\section{Audibility of the Sound of Firing on February I.}

THE following note was recorded here (at Littlemore, Oxford) immediately after I was called away from listening; and as it is more detailed than any I have seen, I daresay you will think it worth printing.

I held my watch in my hand and observed the sequence of the booms for some ten or twelve successive minutes. The second one showed there was regularity, and after the third the facts were clear. The sounds reached us thus :

os. to 20s., continuous unbroken roll of guns of slightly different strength.

20s. to \pm 24 s., silence for $4 \mathrm{~s}$. or $5 \mathrm{~s}$.

\pm 24 s. to \pm 29 s., similar roll.

$\pm 29 \mathrm{~s}$. to $\pm 34 \mathrm{~s}$., silence for $3 \mathrm{~s}$. or $4 \mathrm{~s}$.

\pm 345 . to \pm 38 s., a similar roll.

\pm 38 s. to $42 \mathrm{~s}$., silence to just the $42 \mathrm{~s}$.

42 s. to 45 s. exactly, a short roll culminating in three or four guns much louder than any of the preceding ones.

45 s. to 605 . exactly, dead silence for a quarter minute.

No. I634, VOL. 63]
This recurred with such perfect regularity that there was no doubt whatever about the precision of the observation.

Then I had to ride away on a bicycle about a mile, where I met another cyclist, and we stopped and listened again. The long 20s. roil was now missing, but punctual to the second or two came all the others, the last one with big guns precise.

It seems likely that the long roll was the simultaneous salute of the long line of ships; but I have not yet noticed any authoritative statement as to how the saluting was done. It was interesting to think that at any moment while we were listening there were no fewer than six other such salutes travelling up towards us from the Solent.

From the strength of the sounds I should quite agree with the opinion expressed in Oxford that they might well be heard another twenty miles.

February 12.

\section{The Origin of the "Tumbling" of Pigeons.}

IN reading the account of tumbler pigeons in Darwin's "Animals and Plants under Domestication," the question arose to what the habit of "tumbling" might be due.

I have since seen, in a report of an address by Prof. J. A. Thomson to the North British Branch of the Pharmaceutical Society, a statement that the peculiarities of movement of the Japanese waltzing mouse are due to the fact that only one of its semi-circular canals is developed.

It occurred to me that a similar condition might explain the movements of the tumbler. I should be much obliged if you or any of your readers could tell me where information concerning either of these examples is to be found. $\quad$ E. P.

February 3.

[Prof. Thomson's statement is not quite accurate. The paper to which he referred is undoulstedly that by Rawitz, in Archiv. f. Anat. and Physiol. (Physiol. Abth.), 1899, pp. 236$\mathbf{2 4 4}$, where it is shown that of the three canals the anterior is alone normal, and that the other two-though reduced and abnormal in their inter-relationship-are present.

The physiology of the organ has been since experimentally investigated by Alexander and Kreidl, whose paper is in Pfluger's Archiv. f. Ges. Physiologie (Bd. 82, pp. 541-552); and as to the pigeons, they, too, have all three canals well developed. Concerning their membranous labyrinth, some experiments of interest were made in, I think, the early nineties by Spamer and others, and an account of these and of allied investigations bearing on the question raised (by $\mathrm{McBride}$ ) will be found in the Tourn. Anat. and Physiol. (vol. xvii. pp. 2 I I-2I7). There does not appear to be any foundation for the view to which the writer of the letter inclines. - G. B. Howes.]

\section{Lummer's "Photographic Optics."}

THE interesting review of Prof. Silvanus Thompson's translation of Dr. Otto Lummer's " Photographic Optics," which was published in NATURE on January 3, has come under my notice. I should be obliged if you would permit me to correct a mistake which occurs both in Prof. Thompson's book and the review. Concerning the two views of Munich published in Prof. Thompson's work, which are there attributed to Dr. Miethe, you remark: "Miethe's two views of Munich from a distance of about two miles-the one taken with an ordinary lens, the other with the teleobjective-show what a powerful weapon the latter is."

Both the views in question were taken by my firm, one with an antiplanet and the other with this antiplanet in combination with a magnifying system (negative lens) as a teleobjective of our own construction and manufacture. I send you a prospectus of my firm concerning the said teleobjective and containing also the two views of Munich.

I also observe another error in Prof. Thompson's work; the lenses recently introduced by Messrs. $R$. and J. Beck being described on p. 8o as Messrs. Voigtländers' Collinears, instead of our orthostigmats, for which I have given them a manufacturing license, as you will see in the notice on page $I$ of the prospectus I also send by book post.

München, February 5.

NoTHING could have been further from my intention than to do any injustice to Dr. Steinheil or his firm, and I hasten to acknowledge the justice of his criticisms upon the slips 